\title{
Common Obstetric Emergency \\ (Field Experiences on Community Based Antenatal Risk Screening in Village Level in East Java, Indonesia)
}

Poedji Rochjati

\begin{abstract}
Abstrak
Gawat Obstetrik dibagi dalam 3 kelompok (1) Potensi Risiko dengan adanya riwayat reproduktifobstetrik, (2) Ada Potensi Risiko dengan kondisi medik dan obstetrik, (3) Gawat-Darurat Obstetrik. Berdasarkan skrining risiko antenatal di Poli Hamil RSUD Dr. Soetomo (1976-1985) dan di masyarakat 7 kabupaten di Jawa Timur didapatkan masing-masing berturut-turut $75.5 \%$, 23.3\%, 1.2\% dan $82.2 \%, 16.2 \%, 1.6 \%$ tanpa perbedaan yang bermakna. Skrining antenatal berbasis keluarga di masyarakat oleh ibu-ibu PKK, Dukun dan Bidan di desa telah meningkatkan kepedulian adanya kondisi risiko di antara ibu hamil, suami dan keluarga, telah dapat meningkatkan perilaku upaya pemeriksaan kehamilannya dan meningkatkan kepatuhan untuk melakukan rujukan dini berencana. Manfaat penemuan dini adanya Gawat Obstetrik, secara proporsional tampak pada penurunan persalinan rumah dari $79 \%$ menjadi $68.8 \%$ dan peningkatan persalinan oleh tenaga kesehatan dari 32\% menjadi $62.9 \%$. Rata-rata Angka Kematian Ibu dari 7 kabupaten di Jawa Timur didapatkan 67.4/100.000 kelahiran hidup dengan SE 17/100.000 dan CI 95\%.
\end{abstract}

\begin{abstract}
The obstetric emergency was divided into 3 groups (1) the Potential Risk with obstetric and reproductive history, (2) the Potentially At Risk with medical and obstetric condition, and (3) the Life-threatening condition. Based on the antenatal risk screening in Dr. Soetomo outpatient clinic (1976-1985) and in the community in 7 districts in East Java (1994) the rates were 75.5\%, 23.3\%, 1.2\% and $82.2 \%$, $16.2 \%, 1.6 \%$ respectively with no significant difference between these 2 areas. This family based antenatal risk screening by PKK as women volunteers, TBA and village midwife as the frontline health workers had increased the awareness of risk condition among pregnant refferal The effectiveness of the community, improved health care seeking behaviour and increased compliance for early planned refferal. The effectiveness of the early recognition of the obstetric emergency is shown proportionally in the decrease percentage of home delivery from $79 \%$ to $68.8 \%$ and increased delivery by trained health providers from $32 \%$ to $62.9 \%$. The average Maternal Mortality Ration in this 7 districts in East Java was 67.4/100.000 LB with SE $17 / 100.000$ and CI 95\%.
\end{abstract}

Keywords : Obstetric emergency, antenatal risk screening; maternal health facilities

It was noted that Indonesia had the highest maternal mortality among the Asean countries. The estimated matemal death rate being 421 per 100.000 Live Births, with an interprovincial variation from 130 to 750 maternal deaths per 100.000 LB (National Household Survey, 1992). It is estimated that 20.500 women die each year on account of pregnancy. Haemorrhage,

Department of Obstetrics and Gynecology, Dr. Soetomo Hospital/Faculty of Medicine Airlangga University, Surabaya, Indonesia.

Presented at XVth Asian and Oceanic Congress of Obstetrics and Gynecology, October 15-20, 1995, Bali, Indonesia. sepsis and toxaemia, in that order, constitute the major direct causes of maternal deaths. Most deaths occur during labor, delivery and in the immediate post partum period. Actually, a large proportion of these maternal deaths were preventable with the avoidable associated factors.

In Indonesia approximately $80 \%$ of the population lives in the rural areas. Almost $60-80 \%$ of pregnant women is this rural population do not have ready access to the maternity health care. Antenatal care is available at all levels of the health care system, but the overall national coverage is still below $50 \%$, with the wide provincial variations from 10 to $90 \%$. The in- 
crease number of the maternity facilities has increased access to ANC to $80 \%$. However, according to the Indonesia Demographic and Health Survey, only $56 \%$ have 4 or more visits recommended by the Ministry of Health. Delivery care, most women continue to be attended by the traditional birth attendants (TBA). Nearly $78 \%$ of women first seek delivery assistance from TBAs and relatives. Midwives are the first delivery assistance sought for $18 \%$ of rural deliveries. Overall $79 \%$ of births take place at home.

Several factors influence this low utilization of the maternity health facilities, like ignorancy, low motivation to travel long distances for antenatal care, poverty, and lack of transport for timely obstetric emergency referral. Many women were unable to reach the district hospital for obstetric emergency within 2 hours of travel from their homes. These pregnant mothers were referred and came in the hospital in a very serious condition. The new expensive and sophisticated technology in the hospital seemed still unnecessary in solving these problems in the rural areas.

\section{PREVENTIVE AND PROMOTIVE APPROACH ON MATERNITY HEALTH CARE}

In the new Law on Health no. 23, 1992 Government of Indonesia has stated a change in orientation from the curative efforts to a preventive and promotive efforts in health care. Specifically for the maternity health care, efforts should be pro-actively implemented, dealing with healthy women and fetus, with sthrengtening the IEC.

\section{Preventive measures to reduce maternal mortality}

In order to provide the necessary preventive measures, routine services and referral care to reduce maternal mortality in the village level, a three-pronged approach was implemented : 1) a stronger community based maternity health care, mainly by Bidan di Desa and other nonformal health workers like TBAs, PKK cadres, to screen pregnant women, identify those at risk, followed by IEC to women/husband/immediate family for their awareness of the danger signs and refer as appropriate, 2) a stronger referral back-up network of health centers with beds and hospitals to take care the increasing awareness and compliance for early planned referral of the high risk mothers and prompt timely referral of the obstetric emergency, 3) an alarm and transport system to transfer women with high risk pregnancy and emergencies from the community to referral facilities in time.

\section{THE DEVELOPMENT OF THE COMMUNITY BASED ANTENATAL RISK SCREENING FOR THE OBSTETRIC EMERGENCY}

In 1975 this Risk Approach Strategy for pregnant women with the slogan: Something for all, but more for those in need-in proportion to that need' (WHO, 1978) was implemented and a High Risk Clinic was set up for the first time in Dr. Soetomo Hospital, Surabaya the capital city of East Java Province. The criteria for the obstetric emergency and pregnant women with high risk condition was developed. Antenatal risk screening was conducted followed by an intensive antenatal care for the high risk women, plan for safe delivery was discussed and recorded in the medical record as an information for the provider attended her delivery. In 1981 this antenatal risk screening was applied by the midwife in the community, outside the hospital, in Sidoarjo district.

Then operational studies on Risk Approach Strategy for pregnant women in primary health care level had been conducted in 2 districts in East Java, Sidoarjo (1989), and Lamongan (1991). Study in Sidoarjo was conducted to investigate the possibility of an intervention by a community based antenatal risk screening with the involvement and participation of PKK as women health volunteers promote screening, detection of risk factors, give IEC to the pregnant women, move them to seek care for ANC, and urge them for early planned referral if needed. PKK move proactively through door-to-door home visits to pregnant women. Study in Lamongan showed that the TBA could be involved in these efforts, and build a good integrated teamwork between PKK, TBA Bidan di Desa, Health Center doctor and midwife.

In Probolinggo district (1993) a study on the use of an antenatal risk screening and referral by the frontline health workers in the community to reduce poor reproductive outcome, was a collaborative effort between Dr. Soetomo Hospital, School of Medicine Airlangga University with the Provincial, District, Subdistrict health services and PKK as the private sector. This study was financially and technically supported by the Mother Care Project and the USAID.

Based on the result of these studies, an advocacy effort was conducted by the Heads of the Provoncial Health Service, ObsGyn Department, and the research team with the East Java Government's policy maker. In 1994 the community based antenatal risk screening was applied and extended to all distritcs in East Java 
lages, PKKs, TBAs and Bidan di Desa. The training was given by the already trained Health Center's doctor and midwife, they were trained before by the Obsgyn Specialist. The clients were the pregnant women, husbands and family. The system achieved success in training the women-volunteers to interact with the pregnant women, a good integrated teamwork and partnership with TBA and formal health system. The trained PKK functioned well in the role of antenatal outreach worker.

\section{Home visit as a pro-active screening}

PKKs were informed about the new pregnant mother in their village as early as possible through the monthly Mother and Child Awareness Group meeting (KPKIA) in the community, which are attended by pregnant and lactating mothers, Family Planning acceptors, PKK, TBA and midwife. Then home visits were performed by $\mathrm{PKK}$ periodically, once in the 3 rd -8 th month and twice in the 9 th month. Simple examination was performed by PKK by interviewing the pregnant mothers. The obstetric emergencies, as pregnant women with risk factors can be identified by PKK using the relevant leaflets with figures as audiovisual aids. PKKs hold the screening card to remind them of the next due home visit. PKKs do not provide direct health services.

\section{Instrument}

The simplified screening card, was a version previously developed in Dr. Soetomo hospital, as tertiary and teaching hospital of the School of Medicine, Airlangga University in Surabaya, East Java. This card was designed for use by the PKK and other formal and informal health workers, consisted of a checklist of the risk conditions of the pregnant women with the related risk condition during pregnancy by identifying the risk factor on every contact. It is a managerial tool to stimulate communication and participation between PKK, pregnant women with family, TBAs and the formal health system, in improving coverage with ANC, delivery by health personnels, timely referral for obstetric emergencies, planned referral for the high risk obstetric and pregnancy outcome.

Classificiation of obstetric emergency : the At risk and Life-threatening condition

For the easy usage and acceptancy in the training and in the application of the antenatal risk screening by
PKK and other health providers, the obstetric emergency was classified into 3 groups :

1. Pregnant women potentially At-Risk with obstetric and reproductive history, possible risk of maternal or perinatal mortality/morbidity : young primi gravida, elderly primi gravida, secondary primi gravida, youngest child is less than 2 years old, grande multiparae, over 35 years old, Low Height, poor obstetric history, history on difficulty birth \& prior C-Section.

They were easily recognized an antenatal risk screening by PKK on the first home visit by interviewing. To these women, husband and immediate families there was plenty of time to do IEC repeatedly on each visit for early planned referral needed and to refer the still healthy mother and fetus before they are placed in a life-threatening conditions, for intervention to prevent severe health problem.

2. Pregnant women At-Risk, on medical and obstetric condition : diseases of the mother (anaemia, malaria etc), pre-eclampsia, malpresentation, twin pregnancy, hydramnion, intra uterine fetal death and postdate. For these At-risk women, PKK need confirmation by the midwife or doctor.

3. Obstetric Emergency with life-threatening condition : ante-partum bleeding and eclampsia, could be identified easily without physical examination during pregnancy.

A prompt and timely referral is needed with a limited time for IEC, to prepare transportation and hospital expense needed.

The other obstetric emergencies, recognized during labor, delivery and immediate post partum period : obstructed labor, post-partum bleeding, retained of the placenta.

\section{Score System}

For each characteristic and risk condition was assigned a numerical score of 2,4 and 8 . Every pregnant women has an initial score derived from the age and parity. If risk condition is already recognized at the first home visit an additional score is added and a cummulative total score the pregnant women was classified appropriately by $\mathrm{PKK}$ at each home visit into 3 rik groups with each color code, Low Risk (2-4, green), High Risk (6-10, yellow) and Very High Risk group (12 or more, red). A given score could increase over the previous total score but it can not decrease. 


\section{INFORMATION, EDUCATION, COMMUNICA- TION AND MOTIVATION}

Information, education, communication and motivation have a very important role in this Risk Approach Strategy for pregnant women. PKK and the pregnant women; husband and family, both have the same environment imbedded in tradition, religion, social structures and physical location enable the PKK to motivate her movement to seeking care. This mutually interaction is supported by local Bidan di Desa and the already trained TBA :

1) To increase the coverage for antenatal care. The PKK encouraged all pregnant women to attend antenatal care by trained health personnel routinely. Good antenatal care provides an opportunity to assess the general health and state of readiness of a woman for pregnancy; to provide her with adequate health information about pregnancy and childbirth; to screen her for any high risk factors; to make and act upon timely decisions; to utilize a higher level of care and to achieve a higher level of health and comfort.

2) To promote compliance to early planned referral for safe delivery; to Heatlh center for the High Risk and to hospital for the Very High Risk women. The preventive and health promotive efforts for pregnant women about their risk factors were performed by the already trained PKK, in good partnership with the TBA's and local midwife. Planning for safe delivery the place and birth attendant appropriate to the level of care needed through the early planned referral as a referral in utero, was made together by PKK, pregnant women, husband and immediate family, which was also be communicated to the TBA, health providers through the color code posted on the entrance of the women's house.

\section{Standard guidance for IEC to safe delivery}

The use of the total score and the color code of each pregnant women on every contact make easier to give information, educate the women, husbands and family to let them move for better care needed. The allocated total score on each contact indicates the recommended site and birth attendant.

The color code : green for the Low Risk, delivery by TBA at home; yellow for High Risk, delivery by midwife at home, polindes or in the Health center and red for Very High Risk pregnant women, that should be referred and delivered in the hospital.

\begin{tabular}{rlllll}
\hline Total Score & Risk Group & Antenatal Care & Referral in pregnancy & Place of delivery & Attendant \\
\hline $2-4$ & Low Risk & Midwife & No referral & Mother house & TBA, nidwife \\
$6-10$ & High Risk & Midwife, Doctor & Midwife, Health Centre (HC) & House, village birthing hut, HC & Midwife \\
$>12$ & Very High Risk & Doctor & Hospital & Hospital & Doctor
\end{tabular}

\section{EXPERIENCES IN THE ANTENATAL RISK SCREENING FOR OBSTETRIC EMERGENCY IN DR. SOETOMO HOSPITAL AND COM- MUNITY AT VILLAGE LEVEL IN 7 DISTRICTS IN EAST JAVA}

The recognized At-Risk women on antenatal risk screening in Dr. Soetomo hospital was recorded and analyzed descriptively. The profile of common obstetric emergency in Dr. Soetomo outpatient clinic on 43.601 pregnant women within 10 years (19761985) with At-Risk and with life-threatening condition is shown on Table 1.

Table 1 showed that in Dr. Soetomo hospital as a referral hospital, the proportion of the obstetric emergency in the At Risk group I, II, and III was $75.5 \%$, $23.3 \%$ and $1.2 \%$ respectively.
In 1994 in all districts and municipalities in East Java the antenatal risk screening is implemented in the community as one of the sustainable $\mathrm{MCH}$ services. After delivery the pregnancy outcome, the condition of the mother and baby were recorded by PKK in the screening card. The screening cards were collected from PKK in the community, then through Health centers, District and Provincial Health Service to the Safe Motherhood Center in Dr. Soetomo Hospital. Based on the geographical location the Head of Provincial Health Service has chosen 7 districts with the the number of collected screening cards : Bangkalan 083, Jombang 5730, Lamongan 3658 , Lumajang 3613, Magetan 3574, Sidoarjo 2364 and Tulungagung 2108 as the first priority for computerized data analysis. The total number of women was 22.128 . 
Table 1. Obstetric Emergencies with high risk condition and life-threatening condition in Dr. Soetomo outpatient clinic 1976-1985, in 3 At-Risk groups

\begin{tabular}{|c|c|c|c|}
\hline \multirow{2}{*}{$\begin{array}{l}\text { At-Risk } \\
\text { group }\end{array}$} & \multirow[t]{2}{*}{ Obstetric Emergency } & \multicolumn{2}{|c|}{$\mathrm{N}=10.317$} \\
\hline & & n & $\%$ \\
\hline \multirow[t]{10}{*}{ I } & $\begin{array}{l}\text { At } \text { Risk with obstetric and } \\
\text { reproductive history }\end{array}$ & 7.787 & 75.5 \\
\hline & young primi gravida & 150 & 1.5 \\
\hline & elderly primi gravida & 315 & 3.1 \\
\hline & secondary primi gravida & 184 & 1.8 \\
\hline & grande multiparae & 1.375 & 13.3 \\
\hline & over 35 years old & 1.418 & 13.7 \\
\hline & Low Height $\leq 145 \mathrm{~cm}$ & 1.782 & 17.3 \\
\hline & poor obstetric history & 1.778 & 17.2 \\
\hline & history on difficult birth & - & - \\
\hline & prior C-Section. & 785 & 7.6 \\
\hline \multirow[t]{7}{*}{ II } & Suspected At Risk with medical & 2.405 & 23.3 \\
\hline & $\begin{array}{l}\text { and obstetric condition which } \\
\text { require confirmation by } \\
\text { the midwife or doctor }\end{array}$ & & \\
\hline & mother's diseases & 709 & 6.9 \\
\hline & preeclampsia & 204 & 1.9 \\
\hline & malpresentation & 269 & 2.6 \\
\hline & twin pregnancy, hydramnion, & 715 & 6.9 \\
\hline & IUFD, postdate & 508 & 4.9 \\
\hline \multirow[t]{3}{*}{ III } & Life-threatening codition & 125 & 1.2 \\
\hline & bleeding & 125 & 1.2 \\
\hline & eclampsia & - & - \\
\hline
\end{tabular}

\section{CHARACTERISTICS OF THE SCREENED PREGNANT WOMEN}

The 3 major demographic characteristics of the women are the age, parity and education are shown on Tables $1 \mathrm{a}, 1 \mathrm{~b}$ and Figure 1a.

Table 1a. Age distribution of the pregnant women 7 Districts, East Java Province 1994

\begin{tabular}{lccccr}
\hline District & $\begin{array}{c}\text { Number } \\
\text { pregnant } \\
\text { mothers }\end{array}$ & 516 & $17-19$ & $20-34$ & $\geq 35$ \\
\hline Bangkalan & 1083 & 1.5 & 9.4 & 76.1 & 13.0 \\
Jombang & 5730 & 0.3 & 6.2 & 85.5 & 8.1 \\
Lamongan & 3658 & 0.2 & 6.7 & 82.6 & 10.5 \\
Lumajang & 3613 & 1.0 & 15.9 & 75.4 & 7.7 \\
Magetan & 3574 & 0.4 & 4.1 & 90.1 & 5.5 \\
Sidoarjo & 2364 & 0.1 & 7.2 & 86.3 & 6.5 \\
Tulungagung & 2106 & 1.1 & 8.5 & 85.3 & 5.2 \\
\hline Average & 22128 & 0.5 & 8.0 & 83.7 & 7.8 \\
\hline
\end{tabular}

The optimal childbearing years are between the ages of $20-34$ years $(83.7 \%)$. The further away from the optimal age a woman is (younger or older), the greater the risks of her dying from pregnancy or childbirth, the proportional percentage of these age-groups in each districts is shown on Figure Ia.

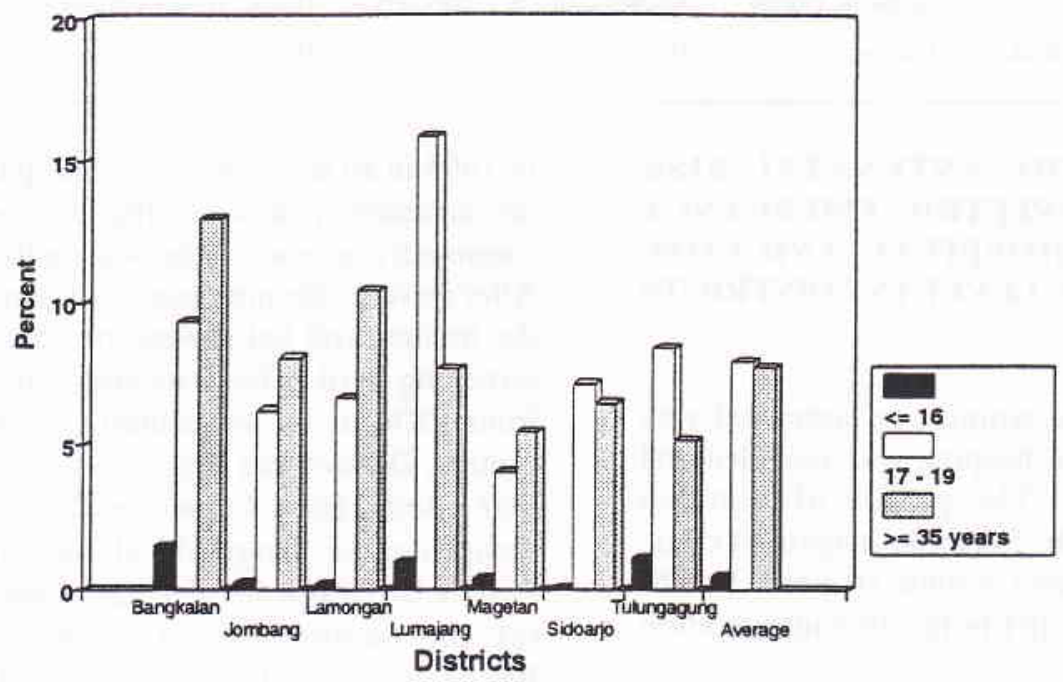

Figure 1a. At-risk age $\leq 19$ years and $\geq 35$ years 
Figure 1a showed that the average percentage on agegroup less than 20 years was $1.3 \%$ with Lumajang as the highest percentage $16.9 \%$. The average percentage on the age-group 35 years or more was $7.8 \%$ with Bangkalan as the highest percentage $13.0 \%$.

In Table $1 \mathrm{~b}$ parity 0 showed the highest percentage in all districts with the inter district variation of parity 0 was $37.1 \%$ to $56.4 \%$, in parity I was lower $25.7 \%$ to $29.4 \%$, in parity II was $10.6 \%$ to $16.3 \%$. The average percentage in all districts the highest was parity 0 $(49.0 \%)$, then parity I (27\%), and then decreasing with the increasing parity.
The educational level of pregnant women is stated in years of education as shown in table Ic

In all districts women with years of education 4-6 years has the highest percentage $42.4 \%-69.9 \%$. with the average $56.0 \%$.

\section{OBSTETRIC EMERGENCY AT THE VILLAGE} LEVEL

Antenatal risk screening was performed on 22.128 pregnant women. The distributon of pregnant women with the 3 AT-Risk groups I, II and III is shown on table 2 .

Table 1b. Parity of the pregnant women 7 Districts in East Java Province, 1984

\begin{tabular}{|c|c|c|c|c|c|c|c|}
\hline \multirow{2}{*}{ District } & \multirow{2}{*}{$\begin{array}{l}\text { Number } \\
\text { pregnant } \\
\text { mothers }\end{array}$} & \multicolumn{6}{|c|}{ Parity (\%) } \\
\hline & & 0 & 1 & 2 & 3 & 4 & $>5$ \\
\hline Bangkalan & 1083 & 37.1 & 26.0 & 76.1 & 8.9 & 4.7 & 6.9 \\
\hline Jombang & 5730 & 46.6 & 27.0 & 85.5 & 6.3 & 3.0 & 3.0 \\
\hline Lamongan & 3658 & 46.1 & 27.8 & 82.6 & 6.2 & 3.7 & 3.4 \\
\hline Lumajang & 3613 & 52.7 & 28.6 & 75.4 & 3.8 & 2.3 & 1.9 \\
\hline Magetan & 3574 & 52.7 & 29.0 & 90.1 & 3.5 & 1.6 & 1.0 \\
\hline Sidoarjo & 2364 & 47.0 & 29.4 & 86.3 & 6.1 & 2.5 & 1.7 \\
\hline Tulungagung & 2106 & 56.4 & 25.7 & 85.3 & 3.9 & 1.0 & 0.8 \\
\hline Average & 22128 & 49.0 & 27.8 & 83.7 & 5.4 & 2.6 & 2.4 \\
\hline
\end{tabular}

Table 1c. Educational status of pregnant women 7 districts, East Java Province, 1994

\begin{tabular}{|c|c|c|c|c|c|c|c|c|}
\hline \multirow{2}{*}{ District } & \multirow{2}{*}{$\begin{array}{l}\text { Number } \\
\text { pregnant } \\
\text { mothers }\end{array}$} & \multicolumn{7}{|c|}{ Years of education - \% } \\
\hline & & 0 & $<4$ & $4-6$ & $7-9$ & $10-12$ & $>12$ & no data \\
\hline Bangkalan & 1083 & 1.3 & - & 54.4 & 4.4 & 6.0 & 0.5 & 33.4 \\
\hline Jombang & 5730 & 0.1 & 18.4 & 49.7 & 22.1 & 9.0 & 0.8 & - \\
\hline Lamongan & 3658 & 0.8 & 0.5 & 58.9 & 23.3 & 7.6 & 0.4 & 8.5 \\
\hline Lumajang & 3613 & 0.3 & 0.8 & 69.9 & 12.2 & 5.7 & 0.5 & 10.5 \\
\hline Magetan & 3574 & 0.5 & 0.8 & 54.5 & 23.8 & 13.1 & 1.1 & 6.2 \\
\hline Sidoarjo & 2364 & 0.3 & 0.1 & 42.4 & 37.2 & 17.2 & 0.9 & 1.8 \\
\hline Tulungagung & 2106 & 0.1 & 0.2 & 62.3 & 18.8 & 12.1 & 1.4 & 5.2 \\
\hline Average & 22128 & 0.4 & 5.1 & 56.0 & 21.4 & 9.9 & 0.8 & 6.5 \\
\hline
\end{tabular}


Table 2. The At-Risk Groups 1, II and III 7 districts East Java Province, 1994

\begin{tabular}{|c|c|c|c|c|c|c|c|c|c|c|c|c|c|c|c|c|}
\hline Districts & \multicolumn{2}{|c|}{ Bangkalan } & \multicolumn{2}{|c|}{ Jombang } & \multicolumn{2}{|c|}{ Lamongan } & \multicolumn{2}{|c|}{ Lumajang } & \multicolumn{2}{|c|}{ Magetan } & \multicolumn{2}{|c|}{ Sidoarjo } & \multicolumn{2}{|c|}{ Tulungagung } & \multicolumn{2}{|c|}{ Average } \\
\hline \multirow[t]{2}{*}{3 At Risk Groups I,II,III } & & 660 & & 771 & & 1387 & & 287 & & 72 & & 84 & & 588 & 704 & 49 \\
\hline & $\mathrm{n}$ & \%group & n & \%group & n & \%group & n & \%group & n & \%group & n & \%group & $\mathrm{n}$ & \%group & n $\%$ & \%group \\
\hline At Risk Group I & 518 & 78.5 & 1542 & 87.1 & 1120 & 80.8 & 1055 & 82.0 & 562 & 83.6 & 533 & 77.9 & 464 & 78.9 & 5794 & 82.2 \\
\hline Young Primi Gravida & & 4.2 & & 0.9 & & 0.4 & & 2.7 & & 2.1 & & 0.6 & & 3.9 & & 1.8 \\
\hline Elderly Primi Gravida & & 2.3 & & 1.6 & & 2.7 & & 3.7 & & 2.1 & & 1.6 & & 3.2 & & 2.5 \\
\hline Scondary Primi Gravida & & 5.2 & & 8.5 & & 7.6 & & 10.0 & & 9.7 & & 4.5 & & 13.3 & & 8.4 \\
\hline Youngest Child $<2$ years & & 10.9 & & 12.4 & & 8.4 & & 11.8 & & 12.2 & & 16.7 & & 16.7 & & 12.1 \\
\hline Grande Multi & & 18.0 & & 19.4 & & 26.0 & & 1.1 & & 13.5 & & 14.5 & & 18.5 & & 16.1 \\
\hline Age,$\geq 35$ years & & 21.4 & & 26.1 & & 27.6 & & 21.7 & & 30.4 & & 22.8 & & 7.1 & & 23.7 \\
\hline Low Height $\leq 145 \mathrm{~cm}$ & & 6.2 & & 9.2 & & 1.9 & & 11.3 & & 5.8 & & 7.2 & & 6.6 & & 7.1 \\
\hline Poor Obstetric History & & 7.0 & & 5.4 & & 3.2 & & 6.6 & & 6.7 & & 5.5 & & 7.0 & & 5.6 \\
\hline History ondifficult birth & & 2.4 & & 2.8 & & 2.1 & & 10.1 & & 0.7 & & 2.9 & & 1.9 & & 3.7 \\
\hline Prior C-Section & & 0.9 & & 0.8 & & 0.8 & & 2.9 & & 0.5 & & 1.6 & & 0.7 & & 1.2 \\
\hline At Risk Group II & 124 & 18.8 & 204 & 11.5 & 251 & 118.1 & 204 & 15.9 & 105 & 15.6 & 141 & 20.6 & 111 & 18.9 & 1140 & 16.2 \\
\hline Mother's diseases & & 7.1 & & 2.1 & & 12.5 & & 5.0 & & 1.9 & & 3.2 & & 2.2 & & 5.2 \\
\hline Preeclampsia & & 1.7 & & 0.7 & & 0.6 & & 1.0 & & 0.9 & & 3.1 & & 3.7 & & 1.3 \\
\hline Malpresentation & & 5.2 & & 4.5 & & 3.2 & & 4.9 & & 2.7 & & 6.6 & & 2.5 & & 4.3 \\
\hline Twin pregnancy & & 0.9 & & 0.9 & & 0.7 & & 1.5 & & 1.9 & & 2.5 & & 7.0 & & 1.7 \\
\hline Hydramnion & & 0.6 & & 0.9 & & 0.2 & & 1.3 & & 0.1 & & 2.4 & & 2.2 & & 1.0 \\
\hline Intra Uterine Fetal Death & & 1.5 & & 0.6 & & 0.7 & & 0.7 & & 0.6 & & 0.4 & & 0.5 & & 0.7 \\
\hline Post Date & & 1.8 & & 1.8 & & 0.2 & & 1.4 & & 7.4 & & 2.5 & & 0.7 & & 1.9 \\
\hline At Risk Group III & 18 & 2.8 & 25 & 1.4 & 16 & $6 \quad 1.1$ & 28 & 2.2 & 5 & 0.7 & 10 & 1.5 & 13 & 2.2 & 115 & 1.6 \\
\hline & & 1.7 & & 1.2 & & 0.9 & & 1.9 & & 0.7 & & 1.1 & & 2.0 & & 1.3 \\
\hline Eclampsia & & 1.1 & & 0.2 & & 0.2 & & 0.2 & & - & & 0.4 & & 0.2 & & 0.3 \\
\hline
\end{tabular}

In Table 2 the profile of the obstetric emergency in all 7 districts is proportionally equal with the profile in Dr. Soetomo hospital with the average on AtRisk group I, II and III $82.2 \%, 16,2 \%$ and $1.6 \%$ respectively.

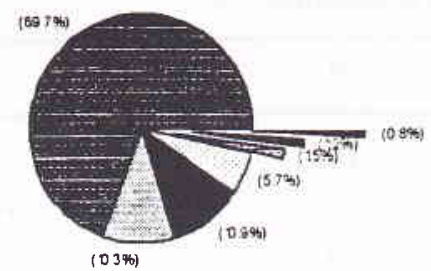

The highest totul score vas 24

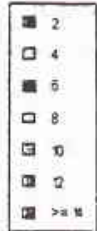

Figure 2. The total score distribution 7 districts East Java Province, 1994

\section{THE TOTAL SCORE AND RISK GROUPS}

The last total score before delivery will be very important for IEC in deciding the place, birth attendant for safe delivery and early planned referall for the At-Risk women is shown on Figure 2, table 3 and Figure 3.

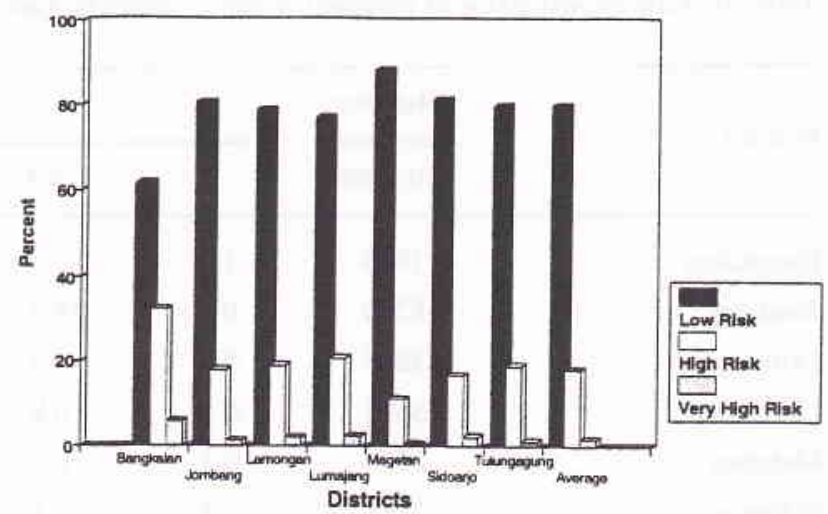

Figure 3. Risk groups : low risk, high risk and very high risk 7 districts, East Java Province, 1994 
Table 3. Risk Groups : Low Risk, High Risk and Very High Risk 7 Districts, East Java Province, 1994.

\begin{tabular}{|c|c|c|c|c|}
\hline \multirow[b]{2}{*}{ Districts } & \multirow{2}{*}{$\begin{array}{c}\text { Number } \\
\text { Pregn. } \\
\text { Women }\end{array}$} & \multicolumn{3}{|c|}{ Risk Groups (\%) } \\
\hline & & $\begin{array}{c}\text { Low Risk } \\
2-4\end{array}$ & $\begin{array}{l}\text { High Risk } \\
6-10\end{array}$ & $\begin{array}{c}\text { Very High Risk } \\
\geq 2\end{array}$ \\
\hline Bangkalan & 1083 & 61.7 & 32.3 & 6.0 \\
\hline Jombang & 5730 & 80.5 & 18.0 & 1.4 \\
\hline Lamongan & 3658 & 79.0 & 18.9 & 2.1 \\
\hline Lumajang & 3613 & 76.9 & 20.6 & 2.5 \\
\hline Magetan & 3574 & 88.3 & 11.0 & 0.7 \\
\hline Sidoarjo & 2364 & 81.3 & 16.5 & 2.2 \\
\hline Tulungagung & 2106 & 79.8 & 19.0 & 1.2 \\
\hline Average & 22128 & 80.0 & 18.1 & 1.9 \\
\hline
\end{tabular}

Figure 2 showed that among 22.128 pregnant women the highest total was 24 . Total score 2 was as the highest percentage $69.8 \%$.

All 22.128 pregnant women in 7 districts were classified into 3 Risk Groups : Low Risk, High Risk and Very Risk and Very High Risk Group as shown on Table 3 and Figure 3.

Table 3 shows the 3 Risk Groups in all 7 districts with Low Risk 61.7\% - 88.3\%, High Risk 11.0\% - 32.3\% and Very High Risk 0.7\%-6.0\%.

From Figure 3 is shown that the average risk group with low Risk $80.0 \%$, High Risk $18.1 \%$ and Very High Risk $1.9 \%$.

\section{ANTENATAL CARE AND DELIVERY BY PLACE \& BIRTH ATTENDANT}

In 7 districts with 22.128 pregnant women antenatal care by the health providers mostly by midwife was received by $70.8 \%$ of women as the average percentage. The inter district variation was from $44.8 \%$ to $87.7 \%$.

Home delivery was still high $68.8 \%$ with the inter district variation of $28.0 \%$ to $89.3 \%$. Women with primary school education $61.5 \%$ in the village still preferred to be delivered at home in a familiar environment and comfort. The second choice for place of delvery was in the midwife's house/polindes $25.0 \%$.

Birth attended by midwife was increasing $61.3 \%$ with the inter district variation of $49.0 \%$ to $83.6 \%$. The average delivery by TBA was $37.1 \%$ and by doctor $1.6 \%$.
In East Java an integrated aporoach and teamwork between TBA and Bidan di Desa in delivery care at the village level was stimulated with midwife as the birth attendant and TBA would be in charge in postpartum care.

\section{RISK ASSESSMENT AND REFERRAL}

Some case-report showed the use-effectiveness of a community based antenatal risk screening in the village, IEC for safe delivery with early planned referral or referral in utero :

1. Mrs $X, 37$, and her husband lived in a village $50 \mathrm{~km}$ from the district hospital. They had 1 child 11 years old, her second pregnancy was premature and born dead. The couple wanted to have another child. In the third month of her third pregnancy a PKK visited her and has recognized some At Risk conditions and also low height $143 \mathrm{~cm}$. The risk factors and the score was assessed by PKK, the total score was 20 , as a very high risk pregnancy with the color code red. To the TBA, midwife and the Health Center's doctor this At Risk condition of Mrs X was informed by PKK. IEC was given to the woman, husband and family. On the following contacts (II-VI) by PKK and ANC by the midwife no any other risk condition identified. Near term she complied to be referred to the hospital, accompanied by the TBA-Primary-C section was performed, both mother and baby with 3800 gram were healthy.

2. Mrs A, 37 years, after 2 years married she got pregnant, but it was a ruptured ectopic pregnancy. In the first years this couple went to the doctor treated for her infertility. After 10 years later she was pregnant. She was visited by PKK in the third 
month of her pregnancy, risk assessment was performed, another risk condition, low height, was recognized and the total score was 16 . She was included in the Very High Risk group, IEC for hospital delivery was given. On the fourth visit PKK saw edema on the legs, she was referred to the midwife, indeed a rise in blood pressure. With this pre-eclampsia the total score became 20 and the woman was referred to the hospital for more intensive evaluation. Close monitoring was conducted. Primary C-Section was performed, mother and baby with the birthweight $2700 \mathrm{grm}$ went home in perfect condition.

The following case is an example of a failure in mobilizing the women for a better care, where no time enough for doing the IEC,

3. Mrs. B, 25 years with ANC in her own village, she was referred to the hospital with postdate. An intensive examination was done, pre-eclampsia and a slight contracted pelvic with a big baby were identified. IEC was given for admission and delivery with the possibility of performing $\mathrm{C}$-section. The woman and her liusband refused to be admitted directly, because they wanted to discuss with their immediate families at home. They didn't come back for delivery. One month later she came back with the story of her home-delivery by TBA and her baby died 10 minutes after the delivery.

\section{MATERNAL MORTALITY}

There were 15 maternal deaths with the main cause of death haemorrhage $9(60 \%)$, obstructed labor 2
$(13,3 \%)$, pre-eclampsia $1(6.7 \%)$ and indirect obstetric deaths 3 (20\%). The Maternal Mortality Ratio in all 7 Districts with the total number of delivery 22.128 is shown on Table 4.

Table 4. Maternal Mortality 7 Districts East Java Province, 1994

\begin{tabular}{lccc}
\hline & Number & \multicolumn{2}{c}{ Maternal Mortality (\%) } \\
\cline { 3 - 4 } Districts & $\begin{array}{r}\text { Pregn. } \\
\text { Women }\end{array}$ & Women dead & MMR/100.000 LB \\
\cline { 3 - 4 } Bangkalan & 1083 & 0 & - \\
Jombang & 5730 & 2 & 35.0 \\
Lamongan & 3658 & 2 & 55.2 \\
Lumajang & 3613 & 6 & 165.0 \\
Magetan & 3574 & 1 & 28.1 \\
Sidoarjo & 2364 & 1 & 42.5 \\
Tulungagung & 2106 & 3 & 62.8 \\
\hline Average & 22128 & 15 & 67.4 \\
\hline
\end{tabular}

Table 4 showed the average MMR of 22.128 women was $67.4 / 100.000$ LB with SE : $17 / 100.000$ and CI $95 \%$ $(33 ; 101) / 100.000$.

The Maternal Mortality Ratio by risk groups Low Risk, High Risk and Very High Risk is shown on table $V$.

Table 5 showed that on further analysis, by the increasing risk on Risk Groups Low Risk, High Risk and Very High Risk there was proportionally an increasing MMR 16.9, 224.7 and 729.9/100.000 LB respectivelly with Chi Sq. : $30,22, \mathrm{df}=1, \mathrm{p}<0,00$.

Table 5. Maternal Mortality by Risk Groups 7 Districts Eats Java Province, 1994

\begin{tabular}{|c|c|c|c|c|c|c|c|c|c|c|}
\hline \multirow{3}{*}{ Districts } & \multirow{3}{*}{$\begin{array}{l}\text { Number } \\
\text { pregnant } \\
\text { women }\end{array}$} & \multicolumn{9}{|c|}{ Maternal mortality ratio by risk groups } \\
\hline & & \multicolumn{3}{|c|}{ Low Risk } & \multicolumn{3}{|c|}{ High Risk } & \multicolumn{3}{|c|}{ Very High Risk } \\
\hline & & $\mathrm{n}$ & women died & MMR & $n$ & women died & MMR & $\mathrm{n}$ & women died & MMR \\
\hline Bangkalan & 1083 & 668 & 0 & - & 350 & 0 & - & 65 & 0 & - \\
\hline Jombang & 5730 & 4615 & 0 & - & 1034 & 2 & 193.4 & 81 & 0 & - \\
\hline Lamongan & 3658 & 2890 & 1 & 34.6 & 693 & 0 & - & 75 & 1 & 1333.3 \\
\hline Lumajang & 3613 & 2779 & 2 & 71.9 & 744 & 2 & 268.8 & 90 & 2 & 2222.2 \\
\hline Magetan & 3574 & 3156 & $\mathbf{0}$ & - & 394 & 1 & 253.8 & 24 & 0 & - \\
\hline Sidoarjo & 2364 & 1923 & 0 & - & 390 & 1 & 256.4 & 51 & 0 & - \\
\hline Tulungagung & 2106 & 1681 & 0 & - & 400 & 3 & 750.0 & 25 & 0 & - \\
\hline Average & 22128 & 17712 & 3 & 16.9 & 4005 & 9 & 224.7 & 441 & 3 & 729.9 \\
\hline
\end{tabular}




\section{LESSONS LEARNED}

In 1994 as the first year of the implementation of the antenatal risk screening in the primary health care level in East Java Provinc by the PKK, TBA and Bidan di Desa as the frontline health workers had increased the awareness of At-Risk and life-threatening condition among pregnant women in the community and improved health care seeking behaviour.

The effectiveness of the early recognition of the obstetric emergency is shown proprotionally in the decrease percentage of home delivery from $79 \%$ to $68.8 \%$ and increased delivery by trained health providers from $32 \%$ to $62.9 \%$.

Compliance for safe delivery still had to be improved through repeated IEC. On the antenatal screening there were $20 \%$ or 4423 At-Risk women identified, which had to be moved and urged to a better place and birth attendant for safe delivery, among these High Risk and Very High Risk women $63.4 \%$ delivered at home and $34.5 \%$ were still delivered by TBAs.

Proportionally the MMR on the High Risk and Very High Risk were 224.7 and 729.9/100.000 LB respec- tively, these MMR were very high compared to the MMR of Low Risk women 16.9/100.000 LB.

The average Maternal Mortality Ratio in this 7 districts in East Java was 67.4/100.000 LB. Haemorrhage 60\% as the most common cause of death, while among these $88.8 \%$ were post-partum haemorrhage.

\section{REFERENCES}

1. Rochjati P. Profile of At-Risk Pregnant Women in 19761985 Dr. Soetomo Hospital, Indon J Obstet Gynecol 1986; 12: $230-48$.

2. Rochjati P, Prabowo P, Abadi A, Soegianto B, Yahya K, Kwast BE. An Antenatal Risk Scoring System East Java Safe Motherhood Study Probolinggo District, East Java, Indonesia, $122^{\text {nd }}$ Annual Meeting APHA, Washington, DC, 1994

3. Rochjati P. The use of Screening Card in the community in reducing Maternal Mortality in 7 districts East Java Province 1995. $9^{\text {th }}$ Annual Meeting ISOG, Surabaya, 1995.

4. Roestam S. Social mobilization of PKK (Family Welfare Movement) to Enhance Child Survival Development in Indonesia. The third International Symposium on Public Health in Asia and Pacific Region. Jakarta-Indonesia Dec. 4-8, 1988.

5. WHO. Risk Approach for Maternal and Child Health Care. WHO Offset Publication No. 39, 1978, 4 and 18-9. 